\title{
Ichtyofaunal Composition and Seasonal Occurrence in the Bodo Creek, Niger Delta, Nigeria.
}

\author{
Nwibari Mesua $W^{1}$. Sikoki, F.D ${ }^{1}$. Wala Chimela ${ }^{2}$ \\ 1.Department of Animal and Environmental Biology, University of Port Harcourt, Nigeria \\ 2.Department of Animal and Environmental Biology Rivers State University, Port Harcourt
}

\begin{abstract}
The studies of Ichthyofaunal composition and seasonal occurrence in Bodo Creek, Niger Delta Nigeria were done between the months of January to July 2010. the collection of the fishes were done with fishing traps, gill and cast nets of various mesh sizes ranging from $20-102 \mathrm{~mm}$. The months of January February and March were sampled for the wet season while the months of May, June and July were sampled for the dry season to determine the seasonal occurrence of the various fish species. The upper, middle and lower courses of the creek were also accorded cognizance during fish collection to determine the spatial dynamics in species occurrence. The identification of the fish species was done with aid of keys provided by Reed etal (1979) Tobor (1978), FAO (1981) and Schneider (1990). A total of 45 fish species belonging 36 genera and 26 families were identified. The fish families; Clupeidaeand Carangidaewere the highest in species number recording 4 species each. The fish families Bagridae, Batrachoidae, Belonidae, Cynoglossidae, Drepanidae, Eleotridae, Elopidae, Ephipidae, Gerreidae, Monodaetylidae, Periophthalmidae, Semandidae, Soleidae, Trichiuridae and Symbrachidae were the least in species number, recording 1 species each. All 45 species occurred in all courses; upper, middle and lower. Courses all 45 species also occurred in both wet and dry season, but Ethmalosafimbriata and Liza grandisquamis were more abundant in the dry season than the wet season.
\end{abstract}

Keywords: Ichthyofauna, assemblage, and distribution

DOI: $10.7176 /$ ALST/74-05

Publication date:May $31^{\text {st }} 2019$

\section{Introduction}

Fish fauna is one of the most diverse group of animals known to man with more than 20,000 species in existence and exist more than all vertebrates put together. Fish is of immense value to man as an important protein source available in the tropics (Sikokietal, 2008). The contribution of fisheries to the Nigeria economy is undisputable significant when viewed from the perspective of supply of high quality dietary and micronutrients income generation, employment creation and the enhancement of foreign exchange earning. It contributed 5.4 percent to gross domestic product in 2002 (Raji, 2007 and Nsentip, 1987)

Artisanal fisheries meet two-third of the fish demand of the Niger Delta States of Rivers, Akwalbom and Cross River, while it accounts for over 80 percent of domestic fish landing of the West African Sub-region. Nigeria's 500,000 metric tones of fish comes for the artisanal sub-sector while commercial trawling; with it's steady decreasing scope in the country contributes less than $10 \%$ of the total marine catch (FAO 1981, Scott 1966, Reid,et. al 1975).

The Bodo Creek is of immense importance for providing a strong livelihood support base for the people of the area and beyond. The Creek serves for fishing and small scale aquaculture, cassava fermentation fuel wood production, water transports and disposal of domestic wastes. The bulk of periwinkle;Trypanotonusfuscatus traded in Bodo City, Gokana Communities and beyond are sourced from Bodo Creek (Onwugbuta-Enyiet. al 2008)

\section{Study Area}

The Bodo Creek is located in Gokana Local Government Area in Ogoni Land Rivers State in the Niger Delta of Nigeria. The study areas has between latitude $6 .{ }^{0} 75$ to $7^{0} 15 \mathrm{~N}$ and longitude $5^{0} 31$ to $5^{0} 35 \mathrm{E}$ with an annual rainfall of between 2,000-3000mm. The rainy season spans from April to November, while the short dry season spans from December to March (Onwugbuta-Enyi, et. al 2008)

The Creek comprises of two man channels namely Kpador Bara and KpadorNwezor, which link the Creek to Opobo, and adjunct between Bonny and Andoni respectively. Both the Kpador Bara and Nwezor inlets form numerous Creek lets; some of which and blindly in mangrove swamps, while some interconnect resulting into mixing flood and ebbing tidal water from both sources.

The study area is associated with some economic importance and biodiversity. Oil exploration and production takes place in the area. Agricultural activities; especially fishing and crop production are the main occupation of the inhabitants of the area.

The vegetation of Bodo Creek comprises generally of red mangroves (Rhizophoraspp) white mangrove (Aviceniaafricanus) Somemacrophytes, Niya Palm (Nypafrusticans) and mangrove fern (Acrosticumaureum) 
also constitute part of the vegetation of the study area.

\section{Materials \& Methods}

Fish Collection: The collection of fishes was done with fish traps, gill and cost nests with mesh sizes ranging from $20-102 \mathrm{~mm}$. Various types of fishing methods and nets of various mesh sizes were applied in the fish collection process to enhance the catching of all species of fish in the Creek no matter their sizes. Water baths and a 4 litre container of formaldehyde were carried to the various landing sites for fixing of the fishers before they were put in the water baths fish.

Fishers and fish mammies were engaged in the collection process; taking cognizance of the courses (upper, middle and lower courses) from which the fishes were collected. Fish collection done in the months of January March (dry season) were fixed with formaldehyde in labeled water - baths and beakers, taken to the laboratory. Same was done to the fishes collected in the months of May - July (wet season).

Laboratory Procedure: The fishes collected from various courses in the dry and wet seasons were removed from the formaldehyde treated water in the various labeled - water baths and beakers, placed on laboratory trays, rinsed with water from the laboratory taps, mobbed and cleaned with neat dry towels.

The identification of the fishes were done with keys provided by Reed, et. al (1979), Tobor (1978, FAO (1981) and Schneider (1990). The various fish species identified were recorded, store in labeled water baths and beakers containing water treated with formaldehyde for preservation.

\section{Results}

Table 1 Checklist of Fish Species of the Bodo Creek

S/N Fish Families

1. Bagridae

2. Batrachoidae

3. Belonidae

4. Carangidae

$\begin{array}{ll}\text { 5. } & \text { Cichlidae } \\ \text { 6. } & \text { Cynoglossidae } \\ \text { 7. } & \text { Clupeidae }\end{array}$

Tilapias

Tonguesole

Sardines

$\begin{array}{ll}\text { 8. } & \text { Drepanidae } \\ \text { 9. } & \text { Eleotridae } \\ \text { 10. } & \text { Elopidae } \\ \text { 11. } & \text { Epphipidae } \\ \text { 12. } & \text { Gerradae } \\ \text { 13. } & \text { Gobiidae }\end{array}$

14. Haemilidae

5. (Pomadasyidae)

15. Lutjanidae

Grinters

Red snappers

16. Monodactylidae

17. Mugilidae

Finger fishes

Mullet

18. Periophthalmidae

Mudskipper

19. Polynemidae

Threadfins

$\begin{array}{ll}\text { 20. } & \text { Sciaenidae } \\ \text { 21. } & \text { Serrandidae } \\ \text { 22. } & \text { Soleidae }\end{array}$

Croakers

White grouper

Soles

\section{Chrysichthynigrodigitus \\ Batrachoidesliberensis}

Strongylurasenegalensis

Caranxlatus, caraxcrysos

Chrocsconmbruschrysurus

Trachinotusteraia

Sarotherodonmelanotheron

Tilapia guinensis

Cynoglossusmenody

Ethmalosafimbriata,

Ilishaafricana

Sardinellaaurita

Sardinellamadirensis

Drepaneafricana

Eleotricafricana

Eloipslacerta

Chaetodipterusgoreensis

Eucinostomusmelanopterus

Gobioidesansorgii

Gobioidesafricanas

Gorogobiusnigricinatus

Plechtorhynchiusmacrolepsis

Pomadasysjubelini, Pomadasysperotiti

Lutjanusdecaptens

Lutjanusdentatus

Lutjanusgoreensis

Psettiassebae

Liza grandisquamis

Mugilcephalus

Liza falcipinnis

Periophthalmuspapilio

Galeoidesdecadactylus

Polydactylusquadrafilis

Pseudotolytus elongates

Pseudotolitusselegalensis

Epinephelusaeneus

Synapturalucitenica 


$\begin{array}{rlll}\text { 23. } & \text { Sphyraenidae } & \begin{array}{l}\text { Bracuda } \\ \text { Sennats }\end{array} & \begin{array}{l}\text { Sphyraenaafra } \\ \text { Sphyraenasphyraena }\end{array} \\ \text { 24. } & \text { Tetradontidae } & \text { Ephippionguttifer } \\ & & \text { Cutlassfish } & \begin{array}{l}\text { Lagocephaguslacrigatus } \\ \text { Trichiaruslapturus }\end{array} \\ \text { 25. } & \text { Trichuridae } & \text { Swampeal } & \text { Synbrachussp } \\ 26 . & \text { Synbrachidae } & & \end{array}$

Table 2: Fish Species Distribution in various Courses

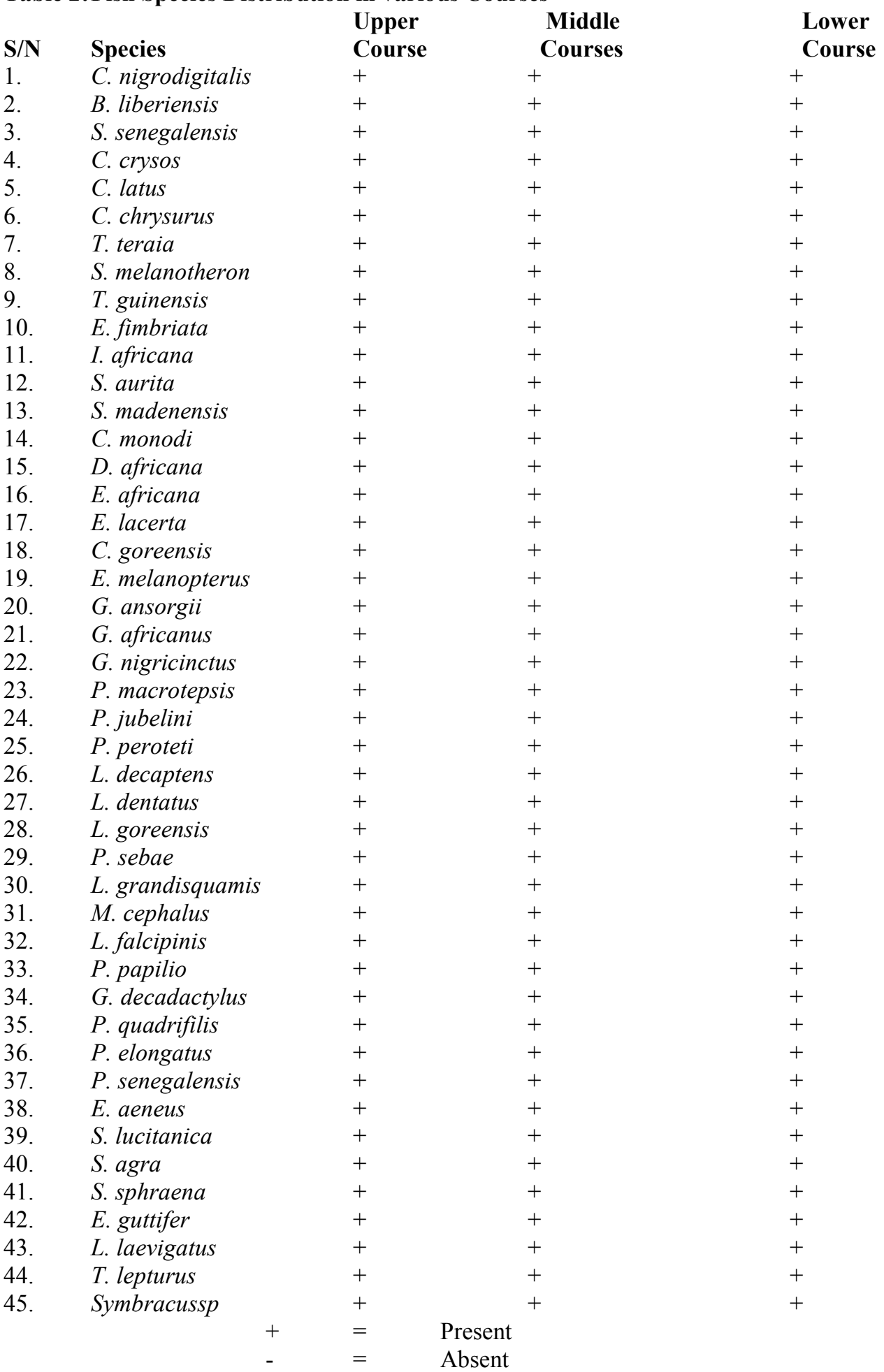




\section{Table 3: Seasonal Occurrence of Fish species in Bodo Creek \\ S/N Fish Species}

1. C. nigrodigitalis

2. B. liberiensis

3. S. senegalensis

4. C. crysos

$5 . \quad$ C. latus

6. C. chrysurus

7. T. teraia

8. S. melanotheron

9. T. guinensis

10. E. fimbriata

11. I. africana

12. S. aurita

13. S. madenensis

14. C. monodi

15. D. africana

16. E. africana

17. E. lacerta

18. C. goreensis

19. E. melanopterus

20. G. ansorgii

21. G. africanus

22. G. nigricinctus

23. P. macrotepsis

24. P.jubelini

25. P. peroteti

26. L. decaptens

$27 . \quad$ L. dentatus

28. L. goreensis

29. P. sebae

30. L. grandisquamis

31. M. cephalus

32. L. falcipinis

33. P. papilio

34. G. decadactylus

35. P. quadrifilis

36. P. elongatus

37. P. senegalensis

38. E. aeneus

39. S. lucitanica

40. S. agra

41. S. sphraena

42. E. guttifer

43. L. laevigatus

44. T. lepturus

45. Symbracussp

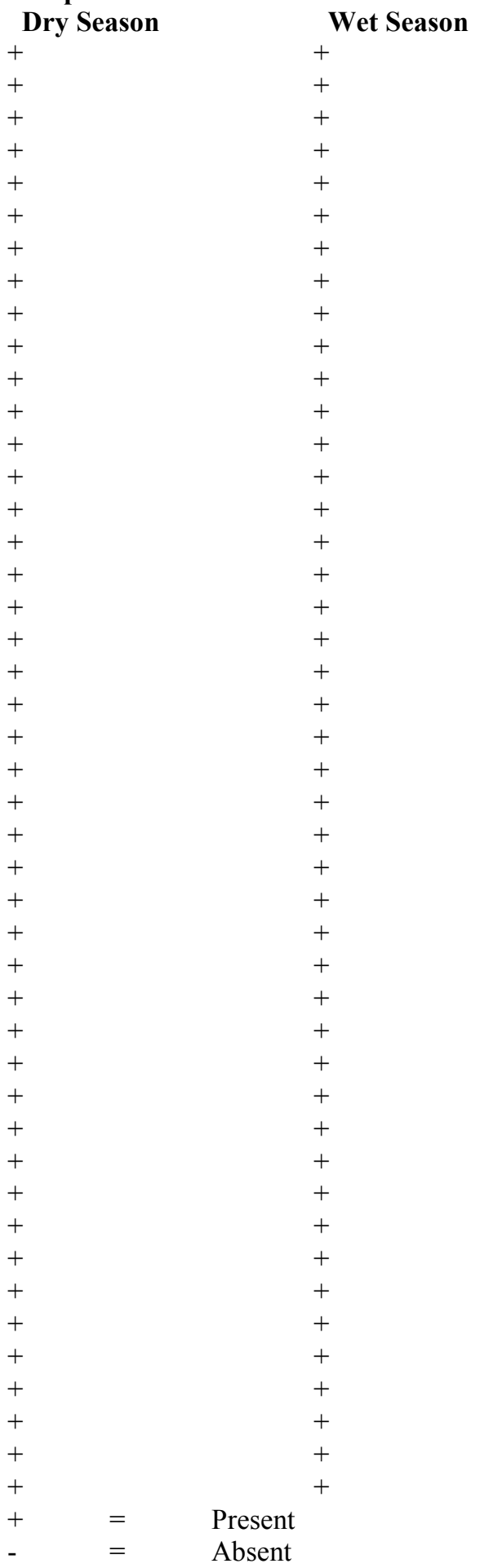

\section{Discussion}

The ichthyofaunal composition of the Bodo Creek of 45 species and 36 genera belonging to 26 families recorded for the body in the study compares favourably with those of brackish water systems (Francis \&Sikoki, 2003).

The fish families clupeidae and carangidae were the highest in species number of four (4) each. Clupeidae (the sardines) recorded four species namely: Ethmalosafimbriata, Ilishaafricana, Sardinellaaurita and Sardinellamadinensis. Carangidae (The Jacks, Moonfish) recorded four (4) species namely: Caranxlatus, Caranxcrysos, Chloroscombuschrysurus and Trachinotusteraia. The fish families Gobiidae, HaemulidaeMugilidae and Lutjanidae were next in high species number of three (3) each.

The lower Bonny River in the Niger Delta of Nigeria recorded 57 fish species belonging to 25 families 
(Chinda, 1994). Francis and Sikoki, 2003), working in the nearby Andoni River System also in the Niger Delta Area of Nigeria recorded 64 fish species from 25 families. The observation difference between the ichthyofaunistic composition of the Bodo Creek and the nearby Andoni River System may not be unconnected with the sampling duration and season.

The relatively more abundance of the families Clupedae, Carangidae, Haemulidae, Lutjanidaeand Mugididaeagrees with Sikoki and Francis (2007) who referred to them as marine migrants that abound in estuaries for the purpose of feeding, shelter before returning to the sea for breeding.

The occurrence of all fish species in the dry and wet seasons may not be unconnected with the tidal system of the creek, the physiological and ecological needs of the fish. Though all fish species occurred in both seasons, some species such as Ethmalosafimbriataand Liza grandisquamis occurred more in the dry season than the wet season.

\section{Conclusion}

The fish species that occurred in the Bodo Creek is evident that it is brachish water system. A total of 45 fish species belonging to 36 genera and 26 families was recorded as the ichthyofaunal composition of the creek. The fish in the creek occurred in both wet and dry seasons. Though some were more in wet season than the dry season. The fish families Clupeidae, Carangidae and Mugilidae were the highest in species number occurrence.

\section{References}

Chinda, A. C. (1994). The Fish Assemblage of the Lower Bonny River African Journal of Ecology, Vol. 32:5565

F.A.O. (1981) Method of Collecting and Analyzing Size and Age Data for Fish Stock Assessment. F.A.O Fish Cire. (736). 100pp

Francis A. and Sikoko F. D. (2003). Studies of the Ichthyofauna of the Andoni River System in Niger Delta Nigeria. African Journal of Interdisciplinary Studies; Vol. 5, No. 1,123-130pp

Nsentip, U.N. (1987). Review of Bonga (EthmalosaFimbriata). Fisheries of the Cross River State, Nigeria. Proceedings of $4^{\text {th }}$ Annual Conference of Fisheries Society of Nigeia (FISON) Port Harcourt. Fishereis Society of Nigeria, Victoria Island, Lagos, Nigeria

Onwugbuta-Enyi, J. Zabbey, N and Erondu, E. S. (2008) Water Quality of Bodo Creek in Lower Niger Delta Basin. Advances in Environmental Biology, 2(3); 132-136pp

Raji, A (2007). Nigerian Fisheries and Attainment of Millenium Development Goals. Fishnet Work, Vol. 4, No, $3 ; 20,21 \mathrm{pp}$.

Reid, W. Burchard, U. J, Hopson, J, Jennes, J. and Taro I. (1979). Fish and fisheries of Northern Nigeria, Ministry of Agriculture, Zaria, Northern Nigeria. 226p

Reid, G. M. and Syndenham, D.H.J. (1979). A checklist of lower Benue River Fish and Ichthyogeographical Review of the Benue River (West Africa). Journal on Natural History. 13:41-47pp

Schneider, W. (1990). FAO Identification Sheets for Fishery Purpose. Field Guide of Marine Resources of Gulf of Guinea, FAO ROME: 3-130.

Scott J.S (1966). Report on Fisheries of Niger Delta Special Area. NDBDA, Port Harcourt, Nigeria. 109pp.

Sikoki F.D and Francis, A. (2007) An Atlas of Fish Fishes of Andoni River in Niger Delta, Nigeria. Molsyfem United Service, Port Harcourt. 1,2pp.

Sikoki, F.D., Zabbey, N and Anyanwu, I.N (2008). Fish Assemblage of Onu-Iyi-Ukwu Streams in South-Eastern Nigeria. Tropical Fish Biology, 17(2); 41-51pp

Tabor, J.C and Ajayi, T.O. (1978). Notes on the Identification of Marine Fishes found on Nigerian Coastal Waters. N10RM Occ 25pp 